\title{
Medical Waste Management: The Need For Effective Regulation of The Minister of Environment And Forestry In Indonesia
}

\author{
Ontran Sumantri Riyanto ${ }^{1 *}$, Adi Purnomo ${ }^{2}$, Yohana Kristiyaning Rahayu ${ }^{3}$, Arif \\ Wahyudi ${ }^{4}$ \\ ${ }^{1}$ Sekolah Tinggi Ilmu Kesehatan Bethesda Yakkum Indonesia. \\ ${ }^{234}$ Universitas 17 Agustus 1945 Semarang Indonesia \\ ${ }^{*}$ Corresponding author: \\ Email: ontran27@yahoo.co.id
}

\begin{abstract}
.
Waste resulting from an activity or production is highly undesirable in human life because waste negatively impacts life, especially for human health. Hospitals are one of the institutions that produce considerable waste and can have a devastating impact on the environment. Because medical waste has the potential to cause problems for the environment as well as to human health. The most dangerous hospital waste is infectious medical waste. Experts and skilled should appropriately handle infectious waste in its management. This research is empirical legal research using a statutory, conceptual, and sociological approach. As well as conducting interviews and observations with the analysis used is qualitative descriptive analysis. It is expected that the management and management of the hospital can carry out the medical waste treatment by the regulations that have been published by the government, and the government must carry out strict supervision so that medical waste does not cause pollution to the environment.
\end{abstract}

Keywords: Hospital, Medical Waste, Environmental Science, pollution, health

\section{INTRODUCTION}

The development of a country indeed produces benefits in all areas of life, including in the health sector. However, apart from producing benefits, the development also causes a change in the impact on the environment and natural resources[1]. Because in essence, development is a change or overhaul towards a better direction by the aspirations. Without development, human welfare would be impossible to achieve, and a good and healthy environment would not be possible[2]. To achieve prosperity and a good and healthy living environment, development must be carried out correctly and consider other aspects. The form of development related to improving the community's health status is the construction of a health service place, one of which is a hospital. Hospital is a health service institution that has the function of providing health services to the community[3]. 
In line with the rapid growth of development, hospitals that were once far from residential areas have now generally changed. It is in the middle of a relatively densely populated settlement. Health service activities in hospitals are also accompanied by garbage or medical waste, among others, in liquids, solids, and gases[4]. A hospital activity process's negative impact is that if the resulting waste is not managed correctly, let alone waste with hazardous and toxic material[5]. Waste hazardous and toxic materials are wastes containing hazardous or toxic materials that, due to their nature and or concentricity, their amounts, either directly or indirectly, can contaminate and damage the environment, endangering the environment, health, and human survival, and other living beings[6]. Given the impact that may arise, it is necessary to implement sound management, including the management of human resources, tools, facilities, finance, and organizing procedures set to obtain hospital conditions that meet environmental health requirements[7].

The quality of the environment can be interpreted with the quality of life because there is the potential for the development of high quality of life in good environmental quality. But the quality of life is subjective and relative because the quality of the environment is subjective and relative. The hospital is one of the producers of hazardous and toxic waste, so the hospital must manage it. As mandated by Government Regulation No. 101 of 2014 in Article 1, number 14, it is written that the Waste Producer of hazardous and toxic materials is Everyone who, because of his business or activities, produces waste hazardous and toxic materials. Suppose the waste producer cannot treat the producer of hazardous and toxic waste. In that case, the producer of hazardous and toxic waste can cooperate with the third party of waste treatment to process the waste. Waste management aims to reduce the risk of pollution to the environment, both directly and indirectly, especially in medical waste classified as hazardous waste[8].

Pollution to the environment has occurred since the beginning of human history. Developed countries, such as America, France, The United Kingdom, and so on, have researched pollution issues[9]. In 1965"s "The Environmental Pollution of the President's Science Advisory Committee," America explained that pollution is a change in our environment to be the ones pleasant or unpleasant, all or mostly, due to influences in energy patterns, chemical compounds, and physics[10]. These changes can affect the environment for human life either directly or indirectly, e.g., by polluting the water supply, damaging agricultural products, damaging nature, which is a means for recreation to admire and appreciate nature.

Hospital waste generally consists of three groups: solid waste, liquid waste, and gas waste. The hospital waste is considered an infectious waste, so it is necessary to separate the waste based on the type of waste strictly[11]. Still, it depends heavily on the type or variety of germs contained in the waste and the type of waste. Some types of waste, germs can grow and develop very well because the germs are by the ideal environmental conditions required by these types of germs, so it is necessary to make 
efforts to control the growth rate and development of germs by using various ways of sewage treatment, the purpose so that the existing germs do not spread.

This has consequences for the need for hospital waste management to protect the public from the dangers of environmental pollution sourced from hospital waste. The solid medical waste consists of solid waste, infectious waste, pathology waste, sharp object waste, pharmaceutical waste, cytolysis waste, chemical waste, radioactive waste, pressurized container waste, and waste with high heavy metal content. Liquid waste and solid waste originating and hospitals are a medium of spread disorder or disease for officers, patients, and the community[12]. Such disturbances can be air pollution, water pollution, soil, food, and beverage pollution. Such pollution to environmental health can have a significant impact on humans[13].

Looking at the impact that can arise, a reasonable management effort is needed, including human resource management, completeness of tools and facilities, finance, and organizing procedures. This aims to obtain the hospital's condition in carrying out the treatment of medical waste that can meet environmental health requirements. In addition to improving the hospital's safety and environmental health and its surroundings, it is necessary to manage, especially the issue of waste that is very dangerous in hospitals.

\section{METHODS}

Based on the problem of waste management of hazardous and toxic materials, normative juridical research methods are carried out through library studies that study especially on secondary data in the form of legislation or other legal documents and research results, assessment results, and other references. Normative juridical methods are a problem approach by conducting studies of legislation and legal theories related to the problem. Another understanding related to research with Normative Juridical type is research by reviewing and analyzing legislation on the subject matter or legal issues in its consistency with legal principles, legal theory including expert opinion.

\section{RESULT AND DISCUSSION}

Hospitals are a significant garbage producer every day and are often toxic, excellent garbage, be it medical waste or non-medical waste. Medical waste characteristics have infectious or toxic properties, and if not properly managed, they will cause pollution. Medical, solid waste is waste derived from medical services, dental care, laboratories, pharmaceuticals or similar, research, treatment, treatment, education that uses toxic materials, infections, or hazardous materials. While nonmedical solid waste is garbage derived from kitchens, hospital offices, courtyards, treatment rooms, radiology, or other activities that are not medically related or that do not contain infectious, toxic, or hazardous materials[14]. 
Hospital sanitation is one of the hospital's activities, where one of the hospital's efforts in the framework of the hospital sanitation service is waste management. Waste management in hospitals is one of the hospital's strategic aspects because good management of medical waste will create the right image for the hospital and realize the quality of the hospital environment's health[15]. That to realize the quality of environmental health, the hospital needs to be set a standard of environmental health quality in the hospital as mandated in Article 1 regulation of the Minister of Health No. 7 of 2019 On Environmental Health Hospital stipulates that the hospital's environmental health regulation aims to: (1) To realize the quality of a healthy environment for the hospital both from physical, chemical, biological, radioactivity, and social aspects. (2) Protect the human resources of hospitals, patients, visitors, and communities around the hospital from environmental risk factors and (3) Creating an eco-friendly hospital.

Waste Management Strategies for hazardous and toxic materials in hospitals can be implemented by implementing several strategies, namely, first promoting and developing waste minimization techniques through clean technology, reuse, reacquisition, and recycling[16]. Awareness of the community. The Third Enhances cooperation between agencies, both central, regional, and international manages waste hazardous and toxic materials. The fourth implements and develops existing laws and regulations and builds Industrial Waste Treatment Centers for Hazardous and Toxic Substances in industrially congested areas.

Medical waste treatment in hospitals is essentially an effort to reduce the volume of waste hazards after activities in the health service through physical, chemical, or biological processes[18]. In the implementation of medical waste management, the mandatory effort is a preventive effort that is to reduce the amount of volume of medical waste released to the environment around the hospital, which includes efforts to reduce waste at the source, if it does not have the waste destruction tool can be handed over to the third party who has permission to do the destruction. The following types of hospital waste:

Clinical Waste. Waste is produced during routine patient service, surgery, and in high-risk units. This waste is dangerous and results in germ infection. It, therefore, needs to be clearly labeled as high risk. Examples of such waste are dirty bandages or wrappers, bodily fluids, amputated limbs, syringe marks, urine bags, and blood products.

Waste Pathology. This waste is also considered high risk and should be autoclave before exiting the pathology unit. The waste should be labeled biohazard. Waste is not a clinic. This waste includes wrapping paper or bags and plastic that is out of contact with bodily fluids. Although it does not pose a risk of illness, the waste is quite troublesome because it requires a large place to transport and dispose of it Kitchen Waste. This waste includes food scraps and dirty water that does not come from infectious waste-producing places. Radioactive Waste. Although this waste does 
not cause infection control problems in hospitals, its disposal safely needs to be appropriately regulated.

About its harmful and toxic characteristics, waste hazardous and toxic materials need to get special treatment not to harm humans and the environment[18]. The impact caused by improper management of hospital waste has been widespread. However, the official report has not been primarily due to cases of waste pollution from hospitals is very sensitive, so many cases of medical waste pollution that are not raised on the surface tend to be resolved in a family way. Management of medical waste must be carried out by the hospital that produces the waste and if the hospital cannot manage the medical waste itself then the management of medical waste can be handed over to other parties.

The process of managing hazardous and toxic waste in hospitals firstly doing the sorting of hazardous and toxic waste materials. In accordance with the Regulation of the Minister of Environment and Forestry of Indonesia states that the sorting of hazardous and toxic waste is carried out by separating hazardous and toxic waste by type, group, and/or characteristics of hazardous and toxic waste[19]. Then accommodate hazardous and toxic waste materials according to the group of hazardous and toxic materials waste. Sorting of medical waste, as well as non-medical waste in hospitals can be done at medical waste producing sources by providing containers to accommodate medical, non-medical waste including sharp-object waste.

The second performs a collection of hazardous and toxic waste materials. Waste collection of hazardous and toxic materials is the activity of collecting hazardous and toxic waste materials from waste producers before being handed over waste processors of hazardous and toxic materials.

The third conducts the storage of hazardous and toxic waste materials. Hazardous and toxic waste should be stored in packaging with clear symbols and labels. Except for sharp object waste and liquid waste, hazardous and toxic waste materials from health care facility activities are generally stored in plastic packaging, containers that have been given plastic waste, or packaging with certain standards such as anticorruption. The most appropriate way to identify waste according to its category is to sort waste according to the color of the packaging and its labels and symbols.

The fourth conducts the process of transporting hazardous and toxic waste materials. For the process of transporting hazardous and toxic materials waste can use special cars and must meet the approval of the transportation of hazardous and toxic materials waste from the government.

Fifth Extermination using an insenerator. Incinerator is a garbage burner operated using combustion technology with a certain temperature. This tool can burn the garbage until it runs out. special medical waste that is infectious, because of the danger character, there are several methods and tools that are well known and commonly used as a means of initial handling, before the processing of chemical 
decontamination for example using disinfectants, the use of steam autoclaving or hydroclaving, microwaves, packaging using special plastic bags[20].

Indonesia's Ministry of Environment and Forestry recorded total infectious medical waste in Indonesia as of June 8, 2020 reaching more than 1,100 tons. Based on local government reports for the handling of hazardous and toxic waste (B3) during the Covid-19 period in Region I Sumatra (Aceh, North Sumatra, West Sumatra, Bengkulu, Jambi, Riau Islands, South Sumatra, Bangka Belitung Islands that have reported, the amount of waste reached 147.62 tons. For Region II Java (Benten, DKI Jakarta, West Java, East Java, and Yogyakarta Special Region that has reported) reached 478.18 tons. As for Region III Bali Nusra reached 200,36 tons, Region IV Kalimantan reached 168.76 tons. For Region V Sulawesi reached 94.89 tons, and Region VI Maluku, Papua and West Papua which has reported reaching 18.73 tons. Provinces that do not have licensed B3 waste treatment are West Sumatra, Bengkulu, North Kalimantan, Gorontalo, North Maluku, Maluku, West Papua and Papua. While there are already medical waste treatment services in Riau Islands, Kalimantan Tim, Banten, South Sulawesi, West Java, Central Java and East Java [21].

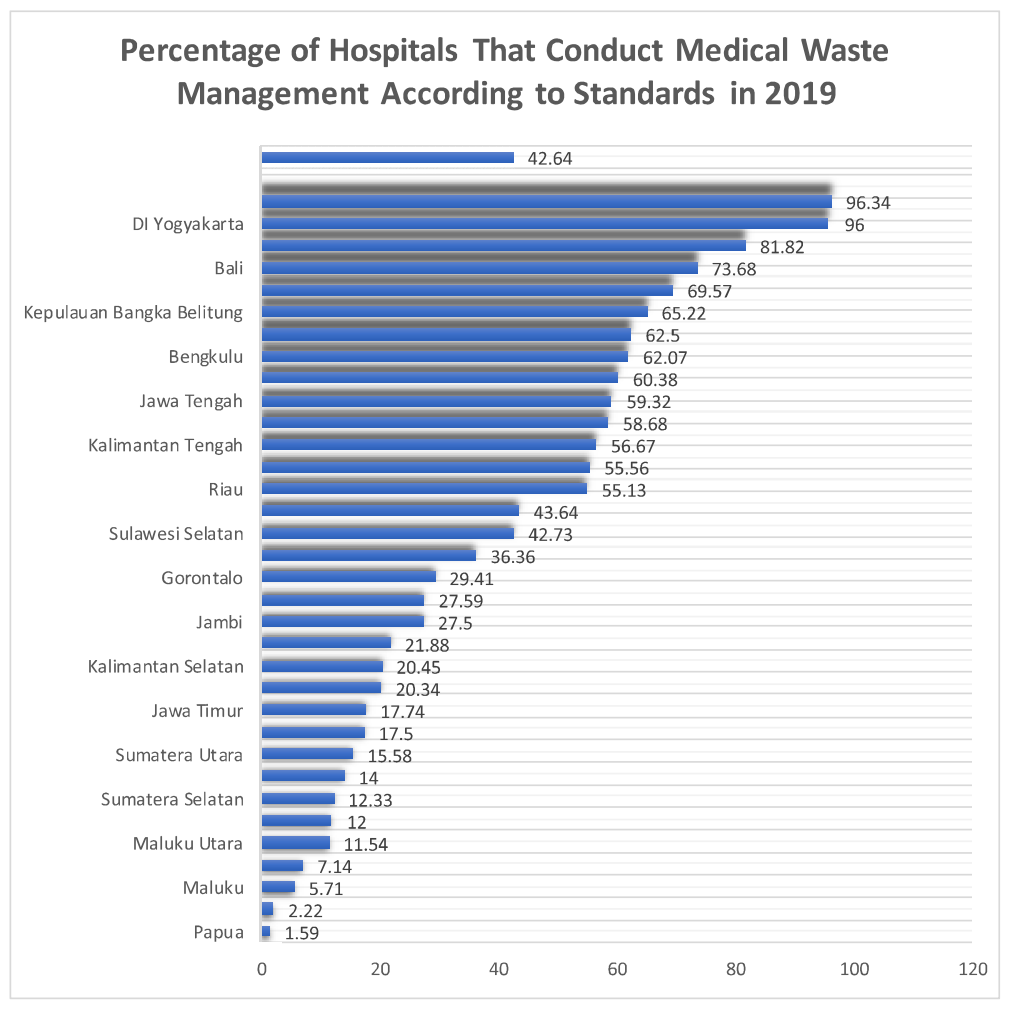

Data source from : Indonesia Health Profile 2019, Ministry of Health RI

The data explained that hospitals that conduct waste management according to standards in 2019 is $42.64 \%$. This figure increased compared to the previous year of 
$33.63 \%$ and has met the 2019 Strategic Plan target of $36 \%$. The provinces with the highest percentage are DKI Jakarta (96.34\%), DI Yogyakarta (96\%), and Lampung $(81.82 \%)$. The provinces with the lowest percentage were Papua $(1.59 \%)$, North Sulawesi $(2.22 \%)$, and Maluku (5.71\%).

\section{CONCLUSION}

There are still many provinces in Indonesia that have not implemented the policy of medical waste management, which is carried out by hospitals must be carried out in accordance with good procedures and also the need for involvement of management to carry out strict and continuous controls related to the management of medical waste in hospitals so that it remains optimal in carrying out waste management and keeping the environment good.

Supervision of hazardous and toxic waste management is carried out in at least two ways, namely verification of hazardous and toxic waste management reports and dumping of hazardous and toxic waste and inspections. The role of the government in terms of licensing and supervising the waste producing parties must be well-equipped and support each other, because the waste produced by hospitals is very dangerous and must be managed properly because if not implemented of course the impact on environmental pollution. The negative impacts arising from ineffective waste management in hospitals are impacting human health, environmental damage and environmental beauty.

\section{REFERENCES}

[1] Z. Yong, X. Gang, W. Guanxing, Z. Tao, and J. Dawei, “Medical waste management in China: A case study of Nanjing," Waste Manag., 2009, doi: 10.1016/j.wasman.2008.10.023, pp. 1376-1382

[2] E. S. Windfeld and M. S. L. Brooks, "Medical waste management - A review," Journal of Environmental Management, 2015, doi: 10.1016/j.jenvman.2015.08.013, pp.98108

[3] L. A. Fraiwan, K. Y. Lweesy, R. J. Oweis, O. Al-Bataineh, and Y. T. Hung, "Medical waste management," in Handbook of Environment and Waste Management: Air and Water Pollution Control, 2012.

[4] Y. W. Cheng, F. C. Sung, Y. Yang, Y. H. Lo, Y. T. Chung, and K. C. Li, "Medical waste production at hospitals and associated factors," Waste Manag., 2009, doi: 10.1016/j.wasman.2008.01.014, pp.440-444

[5] M. M. Abd El-Salam, "Hospital waste management in El-Beheira Governorate, Egypt," J. Environ. Manage , 2010, doi: 10.1016/j.jenvman.2009.08.012, pp. 618-629

[6] J. Conrardy, M. Hillanbrand, S. Myers, and G. F. Nussbaum, "Reducing medical waste," AORN J., 2010, doi: 10.1016/j.aorn.2009.12.029, pp. 711-721

[7] J. I. Blenkharn, "Medical wastes management in the south of Brazil," Waste Management, 2006, doi: 10.1016/j.wasman.2005.09.002, pp. 315-317

[8] M. Saidi and A. Ghaffari, "Waste management," in Design and Operation of Solid http://ijstm.inarah.co.id 
International Journal Of Science, Technology \& Management

Oxide Fuel Cells: The Systems Engineering Vision for Industrial Application, 2019.

[9] B. S. Hale, "Pollution," in The Routledge Handbook of Global Ethics, 2015.

[10] Z. Jiang et al., "Unexpected slowdown of US pollutant emission reduction in the past decade," Proc. Natl. Acad. Sci. U. S. A., 2018, doi: 10.1073/pnas.1801191115, pp.1-6

[11] M. Doble and A. Kumar, "Hospital Waste Treatment," in Biotreatment of Industrial Effluents, 2005. https://doi.org/10.1016/B978-075067838-4/50023-3, pp. 225-232

[12] D. L. Jones, C. Freeman, and A. R. Sánchez-Rodríguez, "Waste Water Treatment," in Encyclopedia of Applied Plant Sciences, 2016. https://doi.org/10.1016/B978-0-12394807-6.00019-8, pp. 352-362

[13] P. Thomas, "Environmental health," in Beyond Bureaucracy?: The Professions in the Contemporary Public Sector, 2018.

[14] M. Stricker, “Hazardous Materials," Iowa Rev., 2013, doi: 10.17077/0021-065x.7290.

[15] A. Demirbas, "Waste management, waste resource facilities and waste conversion processes,” Energy Convers. Manag., 2011, doi: 10.1016/j.enconman.2010.09.025, pp. 1280-1287

[16] K. Ragaert, L. Delva, and K. Van Geem, "Mechanical and chemical recycling of solid plastic waste," Waste Management. 2017, doi: 10.1016/j.wasman.2017.07.044, pp. 2458

[17] Z. M. Shareefdeen, "Medical Waste Management and Control," Journal of Environmental Protection. (Irvine,. Calif)., 2012, doi: 10.4236/jep.2012.312179, pp. 1625-1628

[18] R. Verma, K. S. Vinoda, M. Papireddy, and A. N. S. Gowda, "Toxic Pollutants from Plastic Waste- A Review," Procedia Environ. Sci., 2016, doi: 10.1016/j.proenv.2016.07.069, pp. $701-708$

[19] M. Askarian, P. Heidarpoor, and O. Assadian, “A total quality management approach to healthcare waste management in Namazi Hospital, Iran," Waste Manag., 2010, doi: 10.1016/j.wasman.2010.06.020, pp. 2321-2326

[20] B. K. Lee, M. J. Ellenbecker, and R. Moure-Eraso, "Analyses of the recycling potential of medical plastic wastes," Waste Manag., 2002, doi: 10.1016/S0956-053X(02)000065, pp. 461-470

[21] Media Indonesia, Limbah Medis Indonesia Tembus Lebih dari 1.000 Ton, https://mediaindonesia.com/humaniora/323030/limbah-medis-indonesia-tembus-lebihdari-1000-ton, accessed on July 27, 2020 